\title{
Measurement of Gastrointestinal Protein Loss Using Ceruloplasmin Labeled with ${ }^{67}$ Copper *
}

\author{
Thomas A. Waldmann, $†$ Anatol G. Morell, R. Dean Wochner, Warren \\ Strober, and Irmin Sternlieb \\ (From the Metabolism Branch, National Cancer Institute, National Institutes of Health, \\ Bethesda, Md., and the Department of Medicine, Albert Einstein College of \\ Medicine and Bronx Municipal Hospital Center, New York, N. Y.)
}

Summary. Ceruloplasmin labeled with ${ }^{67}$ copper and administered intravenously to dogs, control human subjects, and patients with excessive gastrointestinal loss was shown to fulfill the requirements for a label for quantification of gastrointestinal protein loss. The radiocopper moiety was poorly absorbed from the gastrointestinal tract, not actively secreted into the intestinal tract, and did not alter significantly the metabolism of ceruloplasmin. Approximately $70 \%$ of the body pool of ceruloplasmin in both dog and man was within the intravascular space. In control human subjects the mean ceruloplasmin concentration was $30 \mathrm{mg}$ per $100 \mathrm{ml}$ with total circulating and total body ceruloplasmin pools of 15.5 and $22 \mathrm{mg}$ per $\mathrm{kg}$, respectively. In patients with excessive gastrointestinal protein loss secondary to intestinal lymphangiectasia, the serum ceruloplasmin concentration was reduced to $16 \mathrm{mg}$ per $100 \mathrm{ml}$ with a comparable reduction in the total circulating and total body ceruloplasmin pools to 8.8 and $12 \mathrm{mg}$ per $\mathrm{kg}$.

The survival.half-time of ceruloplasmin was 6.1 days in normal human subjects and 4.5 days in normal dogs. From 1.0 to $1.9 \%$ of the intravascular pool of ceruloplasmin was lost into the gastrointestinal tract of the dog per day, representing less than $11 \%$ of the over-all metabolism of this protein. In control human subjects from 1.9 to $3.9 \%$ of the intravascular pool was lost into the gastrointestinal tract each day, representing a maximum of from 11 to $22 \%$ of the over-all metabolism of this molecule. In contrast, patients with intestinal lymphangiectasia had a markedly shortened ceruloplasmin survival of 3.1 days, with from 15 to $40 \%$ of the intravascular pool of ceruloplasmin cleared into the gastrointestinal tract daily. This represented $76 \%$ of the over-all metabolism of this protein. Thus, although bulk loss of serum proteins into the gastrointestinal tract does not normally appear to be a significant factor in protein metabolism in normal dogs and men, such loss is a major factor in the pathogenesis of the hypoceruloplasminemia noted in patients with intestinal lymphangiectasia.

\section{Introduction}

Loss of proteins into the gastrointestinal tract has been shown to be a major factor in the patho-

\footnotetext{
* Submitted for publication June 27, 1966; accepted September 14, 1966.

Supported in part by grants from the National Institute of Arthritis and Metabolic Diseases, U. S. Public Health Service (AI-1059 and TI-AM 5384), and the Life Insurance Medical Research Fund (G 62-58).
}

genesis of the hypoproteinemia associated with gastrointestinal disorders (1-6). Because of rapid degradation of proteins in the gastrointestinal lumen and subsequent absorption of the constituent amino acids, nitrogen balance techniques and immunochemical analysis of the gastrointestinal se-

$\dagger$ Address requests for reprints to Dr. Thomas A. Waldmann, Metabolism Branch, National Cancer Institute, Bethesda, Md. 20014. 
cretions have given only qualitative results. Quantitation of the enteric protein loss has been attempted by using macromolecules with radioactive labels (1-8). Requirements for an ideal label for the quantitation of enteric protein loss are: 1) The radioactive label should not alter the survival or distribution of the protein, nor should the label be eluted from the protein. If this requirement is fulfilled, the labeled protein could be used to quantitate simultaneously the rates of intestinal protein loss, endogenous catabolism, and in the steady state, protein synthesis. 2) There should be no absorption of the label from the intestinal tract; otherwise the extent of the gastrointestinal protein loss would be underestimated. 3) There should be no loss of label into the gastrointestinal tract in any form other than as the intact labeled protein. Excretion of unbound label would result in overestimation of the gastrointestinal protein loss. 4) The label should be easy to detect and quantitate in the stools; it should be safe for the subject and should be excreted only minimally in the urine because of possible urinary contamination of the stool.

Iodinated serum protein $(1,2,7)$, iodinated polyvinylpyrrolidone (PVP) (3), and chromiumlabeled albumin (8) have been proposed for the detection of gastrointestinal protein loss. None of these materials fulfills all of the requirements for an ideal label for the quantitation of enteric protein loss. Iodine-labeled proteins cannot be used to quantitate accurately enteric protein loss because of rapid reabsorption of the radioiodide label after the catabolism of the protein in the intestinal lumen and because of secretion of radioiodide in salivary and gastric secretions. These deficiencies have not been overcome with the use of an ion exchange resin (Amberlite) given orally in conjunction with intravenous iodinated albumin, since significant gastric radioiodide secretion persists (9-11). Polyvinylpyrrolidone- ${ }^{131} \mathrm{I}$, a large macromolecule that is poorly absorbed on oral administration, represented a considerable advance in the detection of excessive intestinal protein loss. However, it is not entirely satisfactory for this purpose since PVP is not a protein but a polymer with a wide spectrum of molecular weights and only indirectly gives information on the metabolism of normal serum proteins. In addition variable quantities of PVP-131I are absorbed from the gastrointestinal tract, ranging from 10 to $64 \%$ of the orally administered radioactivity $(3,12)$. Unlike the normal proteins, intravenously administered PVP disappears rapidly from the plasma and is largely excreted in the urine or taken up by the reticuloendothelial system within 48 hours (13).

${ }^{51}$ Chromium-labeled albumin presents certain significant advantages. The radioactive label is neither significantly absorbed from nor actively secreted into the gastrointestinal tract (8). The major disadvantage in the use of ${ }^{51} \mathrm{Cr}$-labeled albumin is that the chromium moiety is gradually eluted from the protein and therefore the ${ }^{51} \mathrm{Cr}$ labeled albumin has a short apparent survival. This precludes the use of ${ }^{51} \mathrm{Cr}$-labeled albumin in the study of endogenous catabolism or synthesis of protein.

Although each of the techniques described for the detection of gastrointestinal protein loss has certain significant limitations, it should be noted that there is agreement in qualitative terms among these methods when there is a marked increase in loss of proteins into the gastrointestinal tract. In contrast, the role of the gastrointestinal tract in the normal metabolism of the serum proteins has been the subject of considerable controversy. Studies using iodinated proteins and intestinal intubation have indicated that gastrointestinal protein loss may normally represent the major factor in the catabolism of albumin $(14,15)$ and gamma globulin (16), whereas albumin- ${ }^{51} \mathrm{Cr}$ studies have indicated that this mechanism is normally of little significance (11).

In an attempt to overcome the limitations of earlier methods, we evaluated ${ }^{67}$ copper-labeled ceruloplasmin as a technique for the quantitation of gastrointestinal protein loss. Ceruloplasmin, a protein of 160,000 molecular weight (17) containing eight copper atoms per molecule, is normally found in serum at concentrations of 20 to $35 \mathrm{mg}$ per $100 \mathrm{ml}$. Sternlieb and co-workers (18) demonstrated previously that although the copper atoms of ceruloplasmin can be exchanged in vitro, there is no exchange of the copper moiety in vivo. Furthermore, exchange labeling of ceruloplasmin in vitro with ${ }^{67} \mathrm{Cu}$ did not alter the biological survival of the protein.

In the present study, ${ }^{67}$ copper-labeled ceruloplasmin administered intravenously was shown to fulfill the major requirements for a label for quan- 
titation of gastrointestinal protein loss. The radiocopper moiety was relatively poorly absorbed from the gastrointestinal tract, not actively secreted into the intestinal tract, and did not significantly alter the metabolism of ceruloplasmin. Radiocopperlabeled ceruloplasmin was used to estimate the size of the circulating and total body ceruloplasmin pools, the rates of synthesis and catabolism of ceruloplasmin, and the role of gastrointestinal loss in ceruloplasmin metabolism of dogs, control human subjects, and patients with intestinal lymphangiectasia. Loss of ceruloplasmin into the gastrointestinal tract was not a significant factor in the metabolism of ceruloplasmin of normal dogs and men. Gastrointestinal protein loss was, however, the major factor in the pathogenesis of the hypoceruloplasminemia noted in patients with intestinal lymphangiectasia.

\section{Methods \\ Preparation and labeling of ceruloplasmin}

The ceruloplasmin used in these experiments was prepared from Cohn Fraction IV-1 of pooled human plasma, with DEAE-cellulose column chromatography and precipitation by an ethanol-chloroform mixture (19). The ceruloplasmin thus obtained for labeling was a clear blue $2 \%$ solution of at least $90 \%$ purity that gave a single precipitation line on Ouchterlony immunodiffusion studies when reacted with antibody to whole human serum and with a specific antihuman ceruloplasmin antibody.

A previously published method for labeling of ceruloplasmin with radiocopper was utilized (18). Ceruloplasmin was incubated with "copper nitrate, 1 ascorbic acid, and a $0.2 \mathrm{M}$ sodium acetate $\mathrm{pH} 5.5$ buffer in vacuo at $37^{\circ}$ for 2 hours. The radiocopper that had not been incorporated into the ceruloplasmin molecule was removed by passing the preparation through a column containing Amberlite IRA 400 resin 2 between two layers of chelex $100 \mathrm{resin}^{3}$ (19). After storage at room temperature overnight, the effluent solution was first passed through a column containing chelex 100 resin and was then filtered through a sterile Millipore filter. The ceruloplasmin used in the studies in man was heated to $60^{\circ} \mathrm{F}$ for 10 hours to exclude any viable hepatitis virus. Over $98 \%$ of the radiocopper of the final product was precipitable with $10 \%$ phosphotungstic acid.

Other parts of the same lot of ceruloplasmin that had not been labeled with the radioactive copper were labeled with ${ }^{10}$ iodine by the iodine monochloride method of McFarlane (20). The final material contained from 0.3 to 1 mole of iodine per mole of ceruloplasmin. Over $99 \%$

\footnotetext{
1 Cyclotron-produced ${ }^{\circ 7} \mathrm{Cu}$ was obtained from Brookhaven National Laboratory, Upton, Long Island, N. Y.

2 Mallinckrodt Chemical Works, St. Louis, Mo.

3 Bio-Rad Laboratories, Richmond, Calif.
}

of the radioiodine of the final product was precipitable with $10 \%$ phosphotungstic acid.

\section{Quantitative determination of ceruloplasmin}

The serum ceruloplasmin concentrations were measured by determining the oxidase activity of serum toward paraphenylenediamine (21) in 185 normal control subjects and in 14 patients ranging in age from 9 to 60 years, with excessive gastrointestinal protein loss demonstrated by using ${ }^{51}$ chromium-labeled albumin (8). Included were 9 patients with intestinal lymphangiectasia (22), 2 with allergic gastroenteropathy (23), 1 with giant rugal hypertrophy, 1 with regional enteritis, and 1 with proteinlosing gastroenteropathy secondary to constrictive pericarditis. None of the subjects had proteinuria, abnormalities of liver function, or significant malabsorption, any of which may affect serum ceruloplasmin concentration.

\section{Determination of intestinal copper absorption}

In order to determine the absorption from the intestinal tract of the ${ }^{67} \mathrm{Cu}$ label of the ceruloplasmin, we administered $5 \mu \mathrm{c}(10 \mathrm{mg})$ of ceruloplasmin $-{ }^{67} \mathrm{Cu}$ orally to six 250-g Sprague-Dawley rats, four mongrel dogs, and eight patients with diseases that did not affect the gastrointestinal tract. The subsequent stools were then collected and counted with appropriate standards to determine the percentage of the orally administered dose of radioactivity that appeared in the stools and was therefore not absorbed. The eight patients received $10 \mathrm{mg}$ of copper sulfate orally three times a day for 2 days before oral administration of ceruloplasmin $-{ }^{67} \mathrm{Cu}$ and throughout the study period to inhibit absorption of any free ${ }^{67}$ copper.

\section{Intravenous administration}

Studies in dogs. Approximately $100 \mathrm{mg}$ of ceruloplasmin labeled with $20 \mu \mathrm{c}$ of ${ }^{67} \mathrm{Cu}$ was injected intravenously into each of five dogs. Four were normal mongrel dogs ranging in weight from 10 to $30 \mathrm{~kg}$. The fifth dog was given $1 \mathrm{mg}$ per $\mathrm{kg}$ nitrogen mustard intraperitoneally before infusion of labeled ceruloplasmin to produce intestinal protein loss similar to that observed in patients with exudative enteropathy. Each dog had been inoculated against distemper, rabies, and hepatitis, dewormed with butyl chloride, and observed for a 2-month period for evidence of infectious disease. They were housed in individual metabolic dog cages, from which the urine and stools could be collected separately.

Studies in man. Approximately $100 \mathrm{mg}$ of ceruloplasmin labeled with $20 \mu \mathrm{c}$ of ${ }^{~} 7$ copper was administered intravenously to four control subjects and to four patients with excessive gastrointestinal protein loss secondary to intestinal lymphangiectasia. This last group had marked hypoalbuminemia, hypogammaglobulinemia, and lymphocytopenia. The half-times of survival of albumin, IgG, and IgM were markedly shortened in all of them. We demonstrated excessive gastrointestinal protein loss in each of these patients with PVP- ${ }^{131} \mathrm{I}$ and albumin- ${ }^{\text {"I }} \mathrm{Cr}$. Three of the subjects used as controls had myotonia dystrophica, and one had aplastic anemia. All of the 
control subjects had normal liver function, total serum protein, and normal albumin concentrations and normal rates of albumin synthesis and catabolism as estimated by albumin-131 I turnover studies.

All subjects received $10 \mathrm{mg}$ of copper sulfate orally three times a day throughout the study period for the purpose of blocking reabsorption of radiocopper by dilution in a relatively large intestinal copper pool.

\section{Quantitative determination of radioactive ${ }^{87}$ copper}

Three to $5 \mathrm{ml}$ of blood was removed at 10 minutes, 4 hours, and at least daily thereafter for the 10-day period of the study. Urine and stool samples were collected in 24-hour lots throughout the study. Two-ml serum samples were counted with appropriate standards in a welltype scintillation counter. The 24-hour urine and stool pools were counted with appropriate standards in a bulktype scintillation counter, with three 2 -inch sodium iodide crystals at $120^{\circ}$ angles.

\section{Calculations}

Plasma radioactivity curves were used to determine plasma volume, fraction of body ceruloplasmin within the intravascular space, rate of transfer of ceruloplasmin between the intra- and extravascular spaces, half-time of ceruloplasmin disappearance, fraction of the intravascular pool of ceruloplasmin catabolized per day, and in the studies in man, rate of ceruloplasmin synthesis. Plasma volume was determined from the quotient of the total radioactivity administered and the activity present per milliliter of plasma at 10 minutes after injection. The protein distribution ratios and the fraction of the intravascular pool catabolized per day were determined according to the method of Matthews (24) as summarized briefly below.

As indicated in Figure 1, plasma radioactivity was plotted as a function of time on semilogarithmic graph paper. The data were analyzed into the sum of two exponentials by the method of "curve peeling." The halftime ( $t_{\frac{1}{3}}$, days) of survival of the protein was determined from the slow exponential curve.

The fraction of the intravascular pool catabolized per day $\left(K_{2,1}\right)$ is given by the following equation: $K_{2,1}=1$ / $\left[\left(C_{1} / b_{1}\right)+\left(C_{2} / b_{2}\right)\right]$, where $-b_{1}$ is equal to the slope of the slower exponential straight line $=0.693 / t_{1}, C_{1}=$ the intercept of this slower exponential straight line with the ordinate, $-b_{2}=$ the slope of the more rapid exponential straight line, and $\mathrm{C}_{2}=$ the intercept of this line with the ordinate.

The fraction of the intravascular protein transferred to the extravascular pool each day $\left(K_{8,1}\right)$ is given by: $K_{8,1}=\left[\left(C_{1} C_{2}\right) \times\left(b_{2}-b_{1}\right)^{2}\right] /\left[\left(C_{1} b_{2}\right)+\left(C_{2} b_{1}\right)\right]$. The fraction of the extravascular protein transferred to the intravascular compartment per day $\left(K_{1,8}\right)$ is given by: $K_{1,3}=C_{1} b_{2}+C_{2} b_{1}$. The distribution of the protein between intra- and extravascular compartments may be calculated from $K_{8,1}$ and $K_{1,8}$ with the relation: extravascular protein mass/intravascular protein mass $=\mathrm{K}_{\mathbf{8}, \mathbf{1}} / \mathrm{K}_{\mathbf{1 , 3}}$.

The rate of ceruloplasmin turnover, which in the steady state equals the rate of synthesis, is given by: cerulo- plasmin synthesis $=K_{2,1} \times$ plasma volume $\times$ serum ceruloplasmin concentration per milliliter.

The rate of loss of ceruloplasmin into the gastrointestinal tract was determined by a clearance method. The fraction of the plasma pool of ceruloplasmin lost into the gastrointestinal tract per day $\left(K_{s}\right)=$ the counts in the stool in the 24-hour period/the counts per milliliter of serum in the period $X$ the plasma volume. We related the counts in the stool to those in the plasma 24 hours before the stool period, thus assuming a 24-hour delay in excretion of material passed into the gastrointestinal tract. The mean of the 24-hour periods from days 2 to 10 was used to determine the $K_{s}$ value. The fraction of the over-all metabolism of ceruloplasmin that is accounted for by gastrointestinal loss is equal to $K_{\mathbf{w}} / \mathrm{K}_{\mathbf{2}, \mathbf{1}}$.

The values for $K_{\text {s }}$ obtained by this method represent a theoretical maximal figure for the fraction of plasma ceruloplasmin ${ }^{87}$ copper cleared into the gastrointestinal tract daily, since unbound ${ }^{\circ 7}$ copper freed from catabolized ceruloplasmin could also enter the gastrointestinal tract in the bile (25) and thus contribute to the radioactivity ultimately measured in the stool. In order to correct for any such loss of unbound ${ }^{~}{ }^{7}$ copper into the gastrointestinal tract and thus determine the clearance of ceruloplasmin into the bowel more accurately, we also evaluated the data

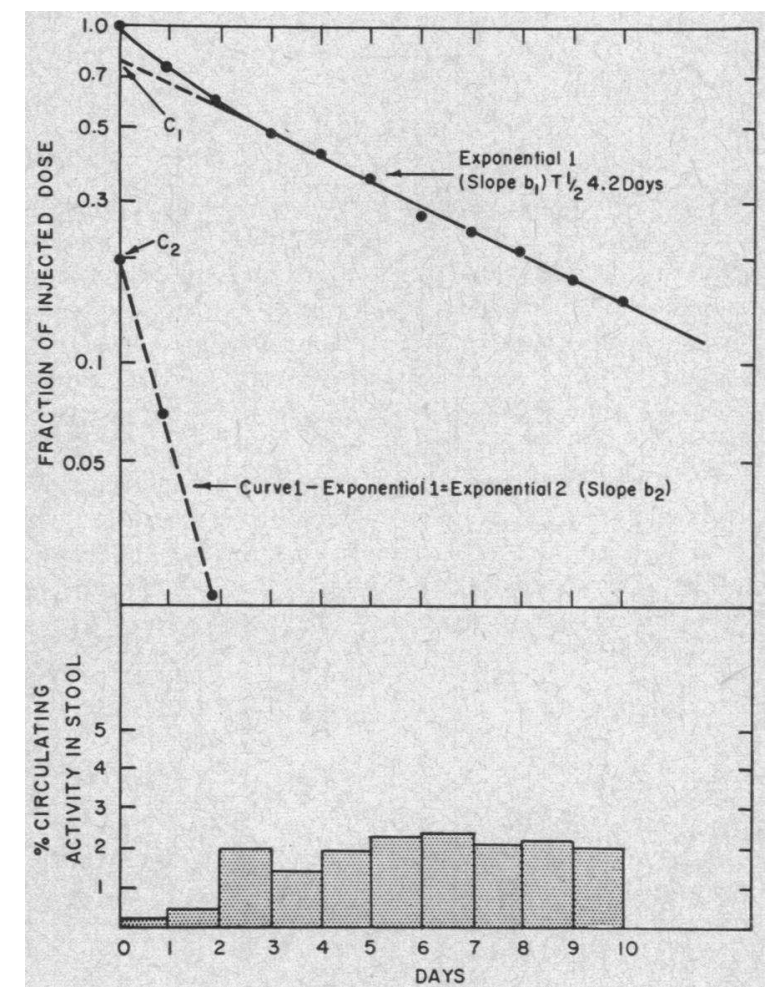

Fig. 1. Analysis of plasma radioactivity curve AFTER INTRAVENOUS ADMINISTRATION OF CERULOPLASMIN${ }^{\circ} \mathrm{CU}$ to THE NORMAL DOG. The fecal clearance of ${ }^{67} \mathrm{Cu}$ derived from the activity excreted in the feces in 24 hours and the corresponding mean plasma activity are also shown. 


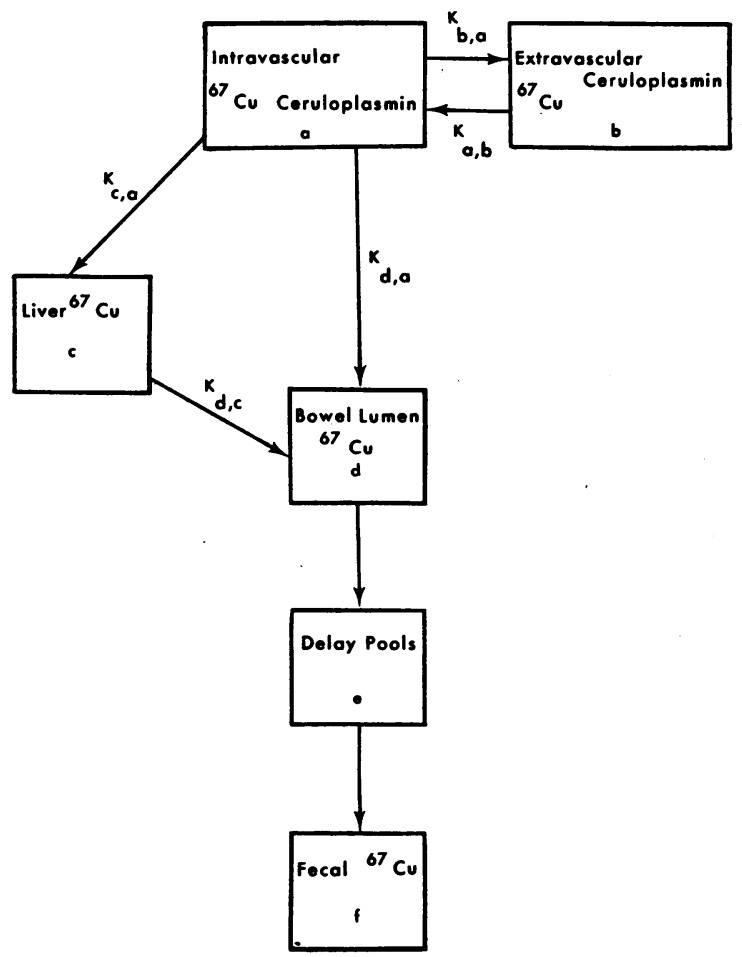

Fig. 2. Kinetic MODEL OF CERULOPLASMin ${ }^{-7} \mathrm{CU}$ METABOLISM. See text for explanation.

with a method of compartmental analysis elaborated by Berman, Shahn, and Weiss (26). The model used is shown in Figure 2. Compartment a represents the plasma ${ }^{67}$ copper radioactivity; compartment $\mathrm{b}$, the extravascular ${ }^{67}$ copper-labeled ceruloplasmin; compartment $\mathrm{c}$, the liver unbound ${ }^{87}$ copper pool; compartment $d$, the ${ }^{87}$ copper in the bowel lumen; compartment $f$, the fecal radioactivity pool; and compartment e, a series of delay pools representing the time required for radioactivity entering the intestinal lumen to make its appearance in the stool.

The transfer rate $\left(\mathrm{K}_{\mathrm{d}, \mathrm{a}}\right)$ represents the rate of loss of ${ }^{\text {e7 }}$ copper-labeled ceruloplasmin from the plasma into the bowel lumen. $K_{c, a}$ represents the rate of transfer of "copper from the plasma to the liver on catabolism of ceruloplasmin, and $K_{d, c}$ represents the rate of transfer of unbound ${ }^{67}$ copper from the liver into the gastrointestinal tract through the bile.

Experimental data were available for compartments a and f. Initial estimates for the time between loss of radioactivity into the intestinal lumen and its appearance in the stool were obtained from oral ceruloplasmin $-{ }^{-87} \mathrm{Cu}$ studies. Radioactive ${ }^{\circ 7}$ copper-labeled ceruloplasmin was injected into compartment a. Subsequent distribution was assumed to be governed by first-order exponential processes; the amounts of residual labeled material in the various compartments could thus be described by sets of first-order linear differential equations.

Accordingly, the data in appropriate form were fit to sets of equations by a digital computer so that the values for intercompartmental transfer rates $\left(K_{1, j}\right)$ that best fit the data could be calculated. The compartmental analysis corrects for loss of unbound ${ }^{87}$ copper into the bowel and thus provides a more accurate estimate of the true rate of loss of ceruloplasmin $-{ }^{\sigma 7} \mathrm{Cu}$ into the bowel $\left(\mathrm{K}_{\mathrm{d}, \mathrm{a}}\right)$ than does the clearance method $\left(\mathrm{K}_{\mathrm{s}}\right)$.

\section{Effect of method of labeling on survival of protein molecules}

The effect of introduction of radioactive copper into the ceruloplasmin molecule was studied by determining the metabolism of the same lot of ceruloplasmin labeled with ${ }^{125} \mathrm{I}$. Subjects for these studies included the four patients and four control subjects used in the intravenous ceruloplasmin- $-{ }^{\circ 7} \mathrm{Cu}$ studies and six dogs other than those that received the ${ }^{67}$ copper-labeled ceruloplasmin. The patients received 10 drops of saturated solution of potassium iodide each 8 hours during the study period, and the dogs received water containing $0.25 \%$ potassium iodide to inhibit thyroidal uptake of the radioiodine. Fifty microcuries of ${ }^{125} \mathrm{I}$-labeled ceruloplasmin was administered intravenously, and 3- to 5-ml blood samples were removed at 10 minutes, 4 hours, and daily throughout the 10-day study. The serum samples were counted and the data analyzed according to the method of Matthews (24) as presented above.

\section{Results}

Gastrointestinal absorption of ceruloplasmin${ }^{67} \mathrm{Cu}$. After oral administration of ${ }^{67} \mathrm{Cu}$-labeled

TABLE I

Ceruloplasmin- ${ }^{67} \mathrm{Cu}$ turnover in the $\operatorname{dog}^{*}$

\begin{tabular}{|c|c|c|c|c|c|c|c|}
\hline Dog & $\begin{array}{c}\text { \% oral }{ }^{67} \mathrm{Cu} \\
\text { not absorbed }\end{array}$ & $\begin{array}{l}\text { Plasma } \\
\text { volume }\end{array}$ & $\begin{array}{l}\text { \% body } \\
\text { ceruloplasmin in } \\
\text { intravascular } \\
\text { pool }\end{array}$ & $\begin{array}{l}\text { Ceruloplasmin } \\
\text { survival } t_{\mathbf{q}}\end{array}$ & $K_{2,1}$ & $\mathbf{K}_{\mathbf{s}}$ & $\frac{\mathrm{K}_{\mathrm{s}} \times 100}{\mathrm{~K}_{2,1}}$ \\
\hline $\begin{array}{l}1 \\
2 \\
3 \\
4\end{array}$ & $\begin{array}{r}97.1 \\
101.0 \\
82.0 \\
88.7\end{array}$ & $\begin{array}{l}m l / k g \\
41 \\
45 \\
51 \\
39\end{array}$ & $\begin{array}{l}91 \\
94 \\
73 \\
79\end{array}$ & $\begin{array}{l}\text { days } \\
4.3 \\
4.8 \\
4.6 \\
4.2\end{array}$ & $\begin{array}{l}0.18 \\
0.15 \\
0.21 \\
0.21\end{array}$ & $\begin{array}{l}0.019 \\
0.010 \\
0.018 \\
0.017\end{array}$ & $\begin{array}{r}10.6 \\
6.7 \\
8.6 \\
8.1\end{array}$ \\
\hline Mean & 92.2 & 44 & 84 & 4.5 & 0.19 & 0.016 & 8.5 \\
\hline
\end{tabular}

* Abbreviations: $\mathrm{K}_{2,1}=$ fraction of plasma pool catabolized per day; $\mathrm{K}_{\mathrm{s}}=$ fraction of plasma pool cleared into gastrointestinal tract per day. 
ceruloplasmin, from 95 to $100 \%$ (mean 98) of the ${ }^{87} \mathrm{Cu}$ appeared in the stools of the six rats. In the four dogs from 82 to $100 \%$ (mean 92) of the administered dose was excreted in the subsequent stool collections. The eight patients excreted from 70 to $99 \%$ (mean 88 ) of the orally administered copper-labeled ceruloplasmin in the subsequent 5-day stool collections. Thus, the copper moiety of ${ }^{67}$ copper-labeled ceruloplasmin is relatively poorly absorbed from the gastrointestinal tract under the conditions of this experiment.

Metabolism of intravenously administered ceruloplasmin ${ }^{-67} \mathrm{Cu}$ in the dog. The data on turnover of ceruloplasmin ${ }^{67} \mathrm{Cu}$ and ceruloplasmin- ${ }^{131} \mathrm{I}$ in the dog are shown in Tables I and II and Figure 1. On the basis of these studies from 61 to $94 \%$ of the body pool of ceruloplasmin was present in the vascular compartment, with a mean of $84 \%$ for those studies using ceruloplasmin- ${ }^{67} \mathrm{Cu}$ and $75 \%$ for ceruloplasmin- ${ }^{131} \mathrm{I}$. The ${ }^{67} \mathrm{Cu}$-labeled ceruloplasmin had a mean half-time of survival of 4.5 days with $19 \%$ of the intravascular pool catabolized per day. The iodinated ceruloplasmin had a mean $t_{\frac{1}{2}}$ of survival of 3.8 days, with $25 \%$ of the intravascular protein pool catabolized per day.

The ceruloplasmin $-{ }^{67} \mathrm{Cu}$ clearance studies showed that from 1 to $1.9 \%$ of the intravascular pool of radioactive ceruloplasmin was lost into the gastrointestinal tract per day. Thus, gastrointestinal loss could account for only 6.7 to $10.6 \%$ of the total daily catabolism of ${ }^{67} \mathrm{Cu}$-labeled ceruloplasmin. In contrast, the dog that received intraperitoneal ni-
TABLE II

Ceruloplasmin-131 I turnover in the dog

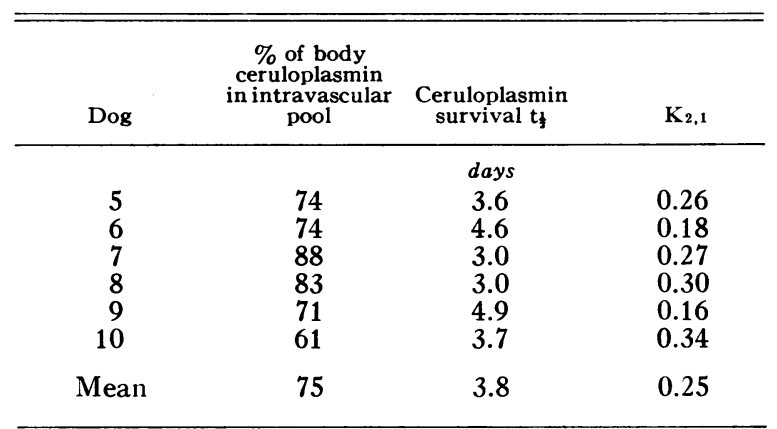

trogen mustard had a survival $t_{t}$ that was markedly reduced to 1.5 days, with over $30 \%$ of the plasma pool of ceruloplasmin lost into the gastrointestinal tract per day.

Only minimal quantities of radioactivity appeared in the urine throughout the period of study in the dog. From 0.01 to $0.3 \%$ of the circulating radioactivity appeared in the urine per day, with a mean of $0.13 \%$ of the circulating radioactivity pool appearing in the urine for a 24 -hour period.

Metabolism of ceruloplasmin- ${ }^{67} \mathrm{Cu}$ in control human subjects. The data on the metabolism of intravenously administered ${ }^{67}$ copper-labeled ceruloplasmin in the four control subjects and the patients with intestinal lymphangiectasia are summarized in Tables III and IV and Figure 3. Approximately $70 \%$ of the body pool of ceruloplasmin was within the intravascular space in the control subjects. These subjects had a mean total circu-

TABLE III

Ceruloplasmin distribution and pool size*

\begin{tabular}{|c|c|c|c|c|c|c|c|}
\hline Patient & $\begin{array}{l}\text { Ceruloplasmin } \\
\text { concentration }\end{array}$ & Plasma volume & $\mathrm{K}_{\mathbf{3}, \mathbf{1}}$ & $\mathbf{K}_{\mathbf{1 , 3}}$ & $\begin{array}{l}\text { \% of body pool } \\
\text { intravascular }\end{array}$ & $\begin{array}{l}\text { Total circulating } \\
\text { ceruloplasmin }\end{array}$ & $\begin{array}{l}\text { Total body } \\
\text { ceruloplasmin }\end{array}$ \\
\hline Control & $m g / 100 m l$ & $\mathrm{ml} / \mathrm{kg}$ & & & & \multicolumn{2}{|c|}{$m g / k g$} \\
\hline $\begin{array}{l}\text { W.J. } \\
\text { J.C. } \\
\text { A.S. } \\
\text { B.J. }\end{array}$ & $\begin{array}{l}45.3 \\
34.0 \\
44.4 \\
33.7\end{array}$ & $\begin{array}{l}44 \\
33 \\
47 \\
30\end{array}$ & $\begin{array}{l}0.37 \\
0.41 \\
0.36 \\
0.36\end{array}$ & $\begin{array}{l}0.86 \\
0.67 \\
0.87 \\
0.79\end{array}$ & $\begin{array}{l}70 \\
67 \\
71 \\
69\end{array}$ & $\begin{array}{l}19.9 \\
11.2 \\
20.9 \\
10.1\end{array}$ & $\begin{array}{l}28.4 \\
16.8 \\
29.8 \\
14.7\end{array}$ \\
\hline Mean & 39.4 & 38 & 0.38 & 0.80 & 69 & 15.5 & 22.4 \\
\hline \multicolumn{8}{|c|}{ Intestinal lymphangiectasia } \\
\hline $\begin{array}{l}\text { L.H. } \\
\text { J.T. } \\
\text { N.B. } \\
\text { I.S. }\end{array}$ & $\begin{array}{l}26.5 \\
25.7 \\
15.9 \\
21.9\end{array}$ & $\begin{array}{l}36 \\
42.4 \\
43.7 \\
35.9\end{array}$ & $\begin{array}{l}0.68 \\
0.46 \\
0.14 \\
0.28\end{array}$ & $\begin{array}{l}1.62 \\
1.00 \\
0.97 \\
0.87\end{array}$ & $\begin{array}{l}70 \\
69 \\
87 \\
76\end{array}$ & $\begin{array}{c}9.54 \\
10.9 \\
6.95 \\
7.86\end{array}$ & $\begin{array}{r}13.6 \\
15.7 \\
8.0 \\
10.4\end{array}$ \\
\hline Mean & 22.5 & 40 & 0.39 & 1.11 & 76 & 8.8 & 11.9 \\
\hline
\end{tabular}

* Abbreviations: $\mathrm{K}_{3,1}=$ fraction of iv (intravascular) pool transferred to ev (extravascular) pool per day; $\mathrm{K}_{1,3}$ $=$ fraction of ev pool transferred to iv pool per day. 
TABLE IV

Rates of ceruloplasmin catabolism and gastrointestinal clearance*

\begin{tabular}{|c|c|c|c|c|c|c|c|}
\hline Patient & $\begin{array}{l}{ }^{67} \mathrm{Cu} \text {-labeled } \\
\text { ceruloplasmin } \\
\text { survival } \mathrm{t}\end{array}$ & $K_{2,1}$ & $\begin{array}{l}\text { Fraction of iv pool } \\
\text { catabolized per day } \\
\text { with ceruloplasmin- } \\
\text { 125I }\end{array}$ & $\begin{array}{c}\text { Ceruloplasmin } \\
\text { turnover } \\
\text { (synthesis) }\end{array}$ & $\mathbf{K}_{\mathbf{s}}$ & $\mathbf{K}_{\mathbf{d}, \mathbf{a}}$ & $\frac{K_{8}}{K_{2,1}} \times 100$ \\
\hline \multicolumn{8}{|l|}{ Control } \\
\hline $\begin{array}{l}\text { W.J. } \\
\text { J.C. } \\
\text { A.S. } \\
\text { B.J. }\end{array}$ & $\begin{array}{l}6.5 \\
6.6 \\
5.8 \\
5.5\end{array}$ & $\begin{array}{l}0.16 \\
0.18 \\
0.18 \\
0.19\end{array}$ & $\begin{array}{l}0.21 \\
0.21 \\
0.22 \\
0.22\end{array}$ & $\begin{array}{l}3.18 \\
2.02 \\
3.76 \\
1.92\end{array}$ & $\begin{array}{l}0.019 \\
0.030 \\
0.039 \\
0.028\end{array}$ & $\begin{array}{l}0.0006 \\
0.013 \\
0.040 \\
0.011\end{array}$ & $\begin{array}{l}11.9 \\
16.7 \\
21.7 \\
14.7\end{array}$ \\
\hline Mean & 6.1 & 0.18 & 0.21 & 2.72 & 0.029 & 0.016 & 16.3 \\
\hline \multicolumn{8}{|c|}{ Intestinal lymphangiectasia } \\
\hline $\begin{array}{l}\text { L.H. } \\
\text { J.T. } \\
\text { N.B. } \\
\text { I.S. }\end{array}$ & $\begin{array}{l}3.3 \\
3.2 \\
2.3 \\
3.6\end{array}$ & $\begin{array}{l}0.31 \\
0.33 \\
0.40 \\
0.26\end{array}$ & $\begin{array}{l}0.45 \\
0.31 \\
0.47 \\
0.38\end{array}$ & $\begin{array}{l}2.96 \\
3.60 \\
2.78 \\
2.04\end{array}$ & $\begin{array}{l}0.29 \\
0.18 \\
0.40 \\
0.15\end{array}$ & $\begin{array}{l}0.25 \\
0.16 \\
0.32 \\
0.14\end{array}$ & $\begin{array}{r}93.5 \\
54.5 \\
100.0 \\
57.8\end{array}$ \\
\hline Mean & 3.1 & 0.33 & 0.40 & 2.84 & 0.26 & 0.22 & 76.5 \\
\hline
\end{tabular}

${ }^{*}$ Abbreviations: $\mathrm{K}_{2,1}=$ fraction of iv pool catabolized per day using ${ }^{67} \mathrm{Cu} ; \mathrm{K}_{8}=$ fecal clearance of ${ }^{67} \mathrm{Cu}$ as fraction of iv pool; $K_{d, a}=$ fraction of circulating ceruloplasmin- ${ }^{67} \mathrm{Cu}$ lost into bowel per day by multicompartmental analysis; $\left(K_{8} / K_{2,1}\right) \times 100=$ per cent of catabolism due to intestinal loss.

lating ceruloplasmin of $15.5 \mathrm{mg}$ per $\mathrm{kg}$ and a total body ceruloplasmin pool of $22.4 \mathrm{mg}$ per $\mathrm{kg}$. The mean ceruloplasmin half-time was 6.1 days, with $17.8 \%$ of the intravascular pool of ceruloplasmin catabolized per day. With ceruloplasmin- ${ }^{125} \mathrm{I}$, the estimates of fractional catabolic rate were slightly

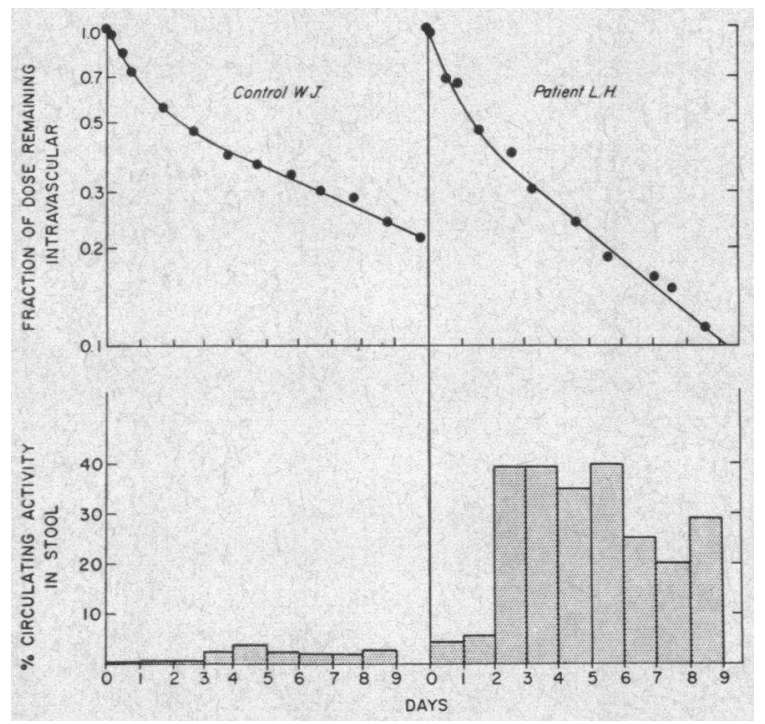

Fig. 3. TURNOVER OF INTRAVENOUSLY ADMinistered CERULOPLASMIN $-{ }^{67} \mathrm{CU}$ IN MAN. The radioactivity remaining in the plasma and the fecal clearance of ${ }^{\circ 7} \mathrm{Cu}$ for a control subject (W.J.) and a patient with intestinal lymphangiectasia (L.H.) are shown. The patient has a shorter ceruloplasmin- ${ }^{\circ 7} \mathrm{Cu}$ survival and a markedly increased fecal clearance of ${ }^{\circ 7} \mathrm{Cu}$ from the plasma. higher than with ${ }^{67}$ copper-labeled ceruloplasmin. The control subjects synthesized a mean of $2.7 \mathrm{mg}$ of ceruloplasmin per $\mathrm{kg}$ per day. The fraction of the plasma pool of ceruloplasmin lost into the gastrointestinal tract per day $\left(\mathrm{K}_{\mathrm{s}}\right)$ estimated from the clearance method ranged from 1.9 to $3.9 \%$ of the intravascular pool per day. Thus, as a maximum, only 11 to $22 \%$ of the total catabolism of ceruloplasmin could be accounted for by gastrointestinal protein loss. The mean fecal clearance of ${ }^{67}$ copperlabeled ceruloplasmin estimated from the multicompartmental analysis was $1.6 \%$ of the intravascular pool per day; this is less than $10 \%$ of the mean catabolic rate of $18 \%$ and confirms that gastrointestinal protein loss normally represents only a minor factor in ceruloplasmin metabolism.

Ceruloplasmin metabolism in patients with intestinal lymphangiectasia and gastrointestinal protein loss. The mean ceruloplasmin concentration of 14 patients with excessive gastrointestinal protein loss was $16.4 \pm 5 \mathrm{mg}$ per $100 \mathrm{ml}$ of serum, compared to $30.7 \pm 3.5$ in 185 normal control subjects $(p<0.01)$. The plasma volume, rates of transfer of ceruloplasmin between the intra- and extravascular pools $\left(\mathrm{K}_{1,3}, \mathrm{~K}_{3,1}\right)$, and the fraction of the body pool of ceruloplasmin in the intravascular compartment were comparable in patients with intestinal lymphangiectasia and control subjects. In patients with intestinal lymphangiectasia, the total circulating ceruloplasmin and total body ceru- 
loplasmin pools were significantly reduced to 8.8 and $11.9 \mathrm{mg}$ per $\mathrm{kg}$, respectively (Table III). The mean half-time of survival of ${ }^{67}$ copper-labeled ceruloplasmin was reduced to 3.1 days, one-half that seen in the control subjects, and the fraction of the intravascular pool of ceruloplasmin $-{ }^{67} \mathrm{Cu}$ catabolized per day was increased to $32.4 \%$ ( Table IV, Figure 3 ). The rate of ceruloplasmin synthesis was $2.8 \mathrm{mg}$ per $\mathrm{kg}$ per day, quite comparable to the 2.7 seen in the control subjects. The patients with intestinal lymphangiectasia had a markedly increased rate of loss of ceruloplasmin into the gastrointestinal tract $\left(\mathrm{K}_{\mathrm{s}}\right)$, with $25.5 \%$ of the intravascular pool cleared per day compared to 2.9 in control subjects. Thus, in the patients with intestinal lymphangiectasia, approximately $75 \%$ of the catabolism of ceruloplasmin was due to intestinal loss of ceruloplasmin, and in contrast to normal subjects this loss represents a major factor in the metabolism of this protein.

\section{Discussion}

In the present study ${ }^{67}$ copper-labeled ceruloplasmin was used to study the turnover of ceruloplasmin in dogs, control human subjects, and patients with excessive gastrointestinal protein loss and was evaluated as a technique for the quantitation of loss of protein into the gastrointestinal tract. The studies reported in this paper could not have been performed with the commonly available ${ }^{64}$ copper because of the short physical halflife (12.8 hours) of this isotope. Availability of the longer lived ${ }^{67}$ copper (half-life, 61.8 hours) enabled us to obtain meaningful measurements of the radioactivity of the serum and stools for sufficiently long periods of observation.

Previous studies in human subjects showed that ceruloplasmin labeled in vitro with ${ }^{67}$ copper was a satisfactory material for the study of the metabolism and distribution of this protein because no exchange of the incorporated copper occurred during the life-span of the molecule in vivo, and thus the radiocopper served as a lifelong label of the protein molecule (18). This conclusion was based on results of studies in two aceruloplasminemic patients with Wilson's disease in whom the rates of disappearance of ${ }^{67}$ copper and of the oxidase activity of the serum were similar after infusion of $1.3 \mathrm{~g}$ of ceruloplasmin ${ }^{67} \mathrm{Cu}$. The half-lives observed in these two patients and in a third normal subject who was infused with ceruloplasmin labeled with ${ }^{67}$ copper in vivo ranged from 4.16 to 5.4 days (18). These values were quite comparable to the results using ${ }^{131} \mathrm{I}$-labeled ceruloplasmin in patients with chronic diseases unrelated to Wilson's disease (27).

In the present study, the behavior of the ${ }^{67}$ copper-labeled ceruloplasmin and that of the iodine-labeled ceruloplasmin were comparable, although the half-lives obtained with the copperlabeled ceruloplasmin were slightly longer than those obtained with the iodinated ceruloplasmin. This discrepancy might represent a short survival of the iodinated ceruloplasmin due to the iodination procedure. Another possible explanation for this difference is reincorporation of ${ }^{67}$ copper released from catabolized ceruloplasmin into newly synthesized ceruloplasmin molecules. Such reincorporation of the radiocopper was minimized in the present studies in man by diluting the liver copper pool with unlabeled copper salts during the experimental period.

In the present studies it was shown that the copper moiety of ceruloplasmin is not very actively absorbed from or secreted into the gastrointestinal tract, in contrast to radioiodine. Although bile is a major route of excretion of nonceruloplasmin copper, it is known from other studies (25), as well as the present studies in normal subjects, that only a small fraction of the daily turnover of ceruloplasmin-copper is excreted directly into the bile. Thus, ${ }^{67}$ copper-labeled ceruloplasmin is the only labeled macromolecule proposed so far that fulfills the three major requirements for adequate quantitation of transfer of serum protein into the gastrointestinal tract. Although it appears to have significant advantages over the other techniques for quantitating gastrointestinal protein loss, the short physical half-life of ${ }^{67}$ copper (61.8 hours) and the difficulty in its production preclude its widespread use in clinical studies where all that is required is the semiquantitative detection of excessive gastrointestinal protein loss. Copper-labeled ceruloplasmin appears to have considerable promise, however, in the study of the role of the gastrointestinal tract in the metabolism of serum proteins where other techniques give conflicting results.

Metabolism of ceruloplasmin- ${ }^{-67} \mathrm{Cu}$ in normal subjects. Ceruloplasmin was shown to be confined 
largely to the intravascular compartment with approximately 70 to $80 \%$ of the body pool of this protein within the intravascular space. Albumin with a molecular weight of 68,000 and gamma globulin (IgG) with a molecular weight of 160,000 have a much lower percentage $(45 \%)$ of their body pool within the intravascular compartment than does ceruloplasmin with a molecular weight of 160,000 . The space of distribution of ceruloplasmin is comparable to that seen previously in studies with fibrinogen-131 I (28) and gamma macroglobulin (29). The total body ceruloplasmin pool of $22 \mathrm{mg}$ per $\mathrm{kg}$ seen in normal subjects in the present study is quite small compared to more than 4,000 for albumin (30), 1,200 for IgG (31), and 190 for fibrinogen (28). The rate of ceruloplasmin synthesis was also markedly less than that observed for these other proteins with a synthetic rate of less than $2 \%$ that of albumin and less than $10 \%$ that of IgG and fibrinogen. The 6.1-day half-time survival of ceruloplasmin seen in the control subjects in the present study is comparable to that observed previously in patients with Wilson's disease (18) and patients with chronic diseases unrelated to Wilson's disease (27). The survival half-time of ceruloplasmin in the dog of 4.5 days is slightly less than that seen in man (25) but considerably longer than 56 hours for rabbit ceruloplasmin in rabbits (25) and 18 to 22 hours for human or mouse ceruloplasmin in the mouse (32).

Role of the normal gastrointestinal tract in ceruloplasmin metabolism. Although there is general agreement that serum proteins can be demonstrated in normal gastrointestinal secretions (33-35), the techniques now available have given conflicting estimates of the quantitative significance of this gastrointestinal loss in the over-all metabolism of serum proteins. A number of workers (14-16) have approached this problem by administering ${ }^{131}$ I-labeled albumin or gamma globulin intravenously and determining the quantity of proteinbound radioiodine appearing in the lumina of isolated segments of the gastrointestinal tract. These authors have concluded that loss of albumin and gamma globulin into the gastrointestinal tract may account for 40 to $100 \%$ of the over-all catabolism of these proteins (14-16). However, other studies suggest that the gastrointestinal tract plays a less significant role in the catabolism of serum proteins. Removal of the subdiaphragmatic gastrointestinal tract has resulted in only a 0 to $10 \%$ prolongation of the survival of iodinated albumin (36-38). ${ }^{51}$ Chromium-labeled albumin has been used to quantitate gastrointestinal protein loss in normal human subjects by relating the daily fecal excretion of chromium to the serum radioactivity curve in a manner comparable to that used for copper-labeled ceruloplasmin in the present study (11). The results of these studies also suggest that less than $10 \%$ of the catabolism of the albumin could be accounted for by enteric protein loss.

The present study using ${ }^{67}$ copper-labeled ceruloplasmin in dogs and control human subjects is in accord with the data using ${ }^{51} \mathrm{chromium}$-labeled albumin in man which suggest that less than $20 \%$ of the daily turnover of ceruloplasmin is accounted for by gastrointestinal loss of the protein. The conclusions of the present study may not necessarily be extended to serum proteins other than ceruloplasmin, since gastrointestinal excretion of these proteins may not parallel that of ceruloplasmin. However, it can be stated that bulk loss of serum or of materials with comparable protein compositions into the gastrointestinal tract is of only minor significance in the protein metabolism of the normal dog and man.

Metabolism of ceruloplasmin in patients with intestinal lymphangiectasia. The serum ceruloplasmin concentration in patients with intestinal lymphangiectasia was reduced below the lower limits of normal. Such reduction may be the result of either diminished synthesis or of increased loss of the protein. Diminished synthesis on a genetic basis accounts for the deficiency that characterizes patients with Wilson's disease (hepatolenticular degeneration) (39). In neonates a diminished rate of synthesis is physiological up to 6 months of age (40). Acquired hypoceruloplasminemia, probably secondary to diminished synthesis, was observed in rare instances of marked hepatic insufficiency $(41,42)$, profound malnutrition (43), and severe intestinal malabsorption (44). In contrast, abnormal losses of ceruloplasmin occur in patients with nephrotic syndrome (40).

In this study patients with intestinal lymphangiectasia were shown to have hypoceruloplasminemia as a result of excessive loss of the copper protein into the bowel. They excreted ceruloplasmin at approximately ten times the rates measured in 
control subjects. The shortened survival of ceruloplasmin as well as that of albumin, fibrinogen, and immunoglobulins $\mathrm{G}, \mathrm{M}$, and $\mathrm{A}$ in the same patients suggested a generalized enteric loss of all serum proteins. Thus, although gastrointestinal excretion plays only a minor role in ceruloplasmin catabolism in normal subjects, bulk fecal loss of ceruloplasmin, as well as of other serum proteins, is the major factor producing the deficiency of ceruloplasmin in patients with intestinal lymphangiectasia.

\section{Acknowledgments}

We are grateful to Drs. Philip Aisen, Cornelius J. A. van der Hamer, James A. McComb, Sam T. Gibson, Lewis H. Larsen, Victor J. Green, and Robert M. Kelty for generous assistance in the purification and preparation of ${ }^{87} \mathrm{Cu}$, and to William Briner for assistance with the labeling of the protein.

\section{References}

1. Schwartz, M., and B. Thomsen. Idiopathic or hypercatabolic hypoproteinaemia: case examined by ${ }^{131}$ I-labelled albumin. Brit. med. J. 1957, 1, 14.

2. Citrin, Y., K. Sterling, and J. A. Halsted. The mechanism of hypoproteinemia associated with giant hypertrophy of the gastric mucosa. New Engl. J. Med. 1957, 257, 906.

3. Gordon, R. S., Jr. Exudative enteropathy: abnormal permeability of the gastrointestinal tract demonstrable with labelled polyvinylpyrrolidone. Lancet 1959, 1, 325.

4. Jeffries, G. H., H. R. Holman, and M. H. Sleisenger. Plasma proteins and the gastrointestinal tract. New Engl. J. Med. 1962, 266, 652.

5. Jarnum, S. Protein-losing Gastroenteropathy. Oxford, Blackwell, 1963.

6. Waldmann, T. A. Protein-losing enteropathy. Gastroenterology 1966, 50, 422.

7. Jeejeebhoy, K. N., and N. F. Coghill. The measurement of gastrointestinal protein loss by a new method. Gut 1961, 2, 123.

8. Waldmann, T. A. Gastrointestinal protein loss demonstrated by ${ }^{51} \mathrm{Cr}$-labelled albumin. Lancet 1961, 2, 121.

9. Jones, J. H., and D. B. Morgan. Measurement of plasma-protein loss into gastrointestinal tract using ${ }^{181}$ I-labelled proteins and oral Amberlite resin. Lancet $1963,1,626$.

10. Freeman, T., and A. H. Gordon. Human and rat intestine as a site of catabolism of albumin? in Protides of the Biological Fluids: Proceedings of the Eleventh Colloquium, H. Peeters, Ed. Amsterdam, Elsevier, 1964, p. 226.

11. Waldmann, T. A., and R. D. Wochner. The use of ${ }^{51} \mathrm{Cr}$-labeled albumin in the study of proteinlosing enteropathy in Protides of the Biological
Fluids: Proceedings of the Eleventh Colloquium, H. Peeters, Ed. Amsterdam, Elsevier, 1964, p. 224.

12. Jarnum, S. The ${ }^{131} \mathrm{I}$-polyvinylpyrrolidone ( ${ }^{181} \mathrm{I}-\mathrm{PVP}$ ) test in gastrointestinal protein loss. Scand. J. clin. Lab. Invest. 1961, 13, 447.

13. Ravin, H. A., A. M. Seligman, and J. Fine. Polyvinyl pyrrolidone as a plasma expander. Studies on its excretion, distribution and metabolism. New Engl. J. Med. 1952, 247, 921.

14. Glenert, J., S. Jarnum, and S. Riemer. The albumin transfer from blood to gastrointestinal tract in dogs. Acta chir. scand. 1962, 124, 63.

15. Wetterfors, J., R. Gullberg, S.-O. Liljedahl, L.-O. Plantin, G. Birke, and B. Olhagen. Role of the stomach and small intestine in albumin breakdown. Acta med. scand. 1960, 168, 347.

16. Andersen, S. B., J. Glenert, and K. Wallevik. Gamma globulin turnover and intestinal degradation of gamma globulin in the dog. J. clin. Invest. 1963, 42, 1873.

17. Kasper, C. B., and H. F. Deutsch. Physicochemical studies of human ceruloplasmin. J. biol. Chem. 1963, 238, 2325.

18. Sternlieb, I., A. G. Morell, W. D. Tucker, M. W. Greene, and I. H. Scheinberg. The incorporation of copper into ceruloplasmin in vivo: studies with copper $^{64}$ and copper ${ }^{67}$. J. clin. Invest. 1961, 40, 1834.

19. Morell, A. G., P. Aisen, and I. H. Scheinberg. Is ceruloplasmin an ascorbic acid oxidase? J. biol. Chem. 1962, 237, 3455.

20. McFarlane, A. S. Efficient trace-labelling of proteins with iodine. Nature (Lond.) 1958, 182, 53.

21. Scheinberg, I. H., and A. G. Morell. Exchange of ceruloplasmin copper with ionic $\mathrm{Cu}^{\text {at }}$ with reference to Wilson's disease. J. clin. Invest. 1957, 36, 1193.

22. Waldmann, T. A., J. L. Steinfeld, T. F. Dutcher, J. D. Davidson, and R. S. Gordon, Jr. The role of the gastrointestinal system in "idiopathic hypoproteinemia." Gastroenterology 1961, 41, 197.

23. Waldmann, T. A., R. D. Wochner, L. Laster, and R. S. Gordon, Jr. Allergic gastroenteropathy: a cause of excessive gastrointestinal protein loss. In preparation.

24. Matthews, C. M. E. The theory of tracer experiments with ${ }^{181}$ I-labelled plasma proteins. Phys. in Med. Biol. 1957, 2, 36.

25. Aisen, P., A. G. Morell, S. Alpert, and I. Sternlieb. Biliary excretion of cæruloplasmin copper. Nature (Lond.) 1964, 203, 873.

26. Berman, M., E. Shahn, and M. F. Weiss. The routine fitting of kinetic data to models: a mathematical formalism for digital computers. Biophys. J. 1962, 2, 275.

27. Gitlin, D., and C. A. Janeway. Genetic alterations in plasma proteins of man in The Plasma Proteins, F. W. Putnam, Ed. New York, Academic Press, 1960, vol. 2, p. 407. 
28. McFarlane, A. S., D. Todd, and S. Cromwell. Fibrinogen catabolism in humans. Clin. Sci. 1964, 26, 415.

29. Barth, W. F., R. D. Wochner, T. A. Waldmann, and J. L. Fahey. Metabolism of human gamma macroglobulins. J. clin. Invest. 1964, 43, 1036.

30. Berson, S. A., R. S. Yalow, S. S. Schreiber, and J. Post. Tracer experiments with $I^{128}$ labeled human serum albumin: distribution and degradation studies. J. clin. Invest. 1953, 32, 746.

31. Solomon, A., T. A. Waldmann, and J. L. Fahey. Metabolism of normal $6.6 \mathrm{~S} \gamma$-globulin in normal subjects and in patients with macroglobulinemia and multiple myeloma. J. Lab. clin. Med. 1963, $62,1$.

32. Gitlin, D., and C. A. Janeway. Turnover of the copper and protein moieties of ceruloplasmin. $\mathrm{Na}$ ture (Lond.) 1960, 185, 693.

33. Gullberg, R., and B. Olhagen. Electrophoresis of human gastric juice. Nature (Lond.) 1959, 184, 1848.

34. Holman, H., W. F. Nickel, Jr., and M. H. Sleisenger. Hypoproteinemia antedating intestinal lesions, and possibly due to excessive serum protein loss into the intestine. Amer. J. Med. 1959, 27, 963.

35. Nusslé, D., S. Barandun, H. P. Witschi, H. Käser, M. Bettex, and P. Girardet. Déperdition intestinale de protéines plasmatiques chez l'enfant. Helv. paediat. Acta 1962, 16 (suppl. 10), 1.
36. Gitlin, D., J. R. Klinenberg, and W. L. Hughes. Site of catabolism of serum albumin. Nature (Lond.) 1958, 181, 1064.

37. Katz, J., S. Rosenfeld, and A. L. Sellers. Sites of plasma albumin catabolism in the rat. Amer. J. Physiol. 1961, 200, 1301.

38. Franks, J. J., K. W. Edwards, W. W. Lackey, and J. B. Fitzgerald. The role of the gut in albumin catabolism: II. Studies in enterectomized rabbits. J. gen. Physiol. 1962, 46, 427.

39. Scheinberg, I. H., and I. Sternlieb. Wilson's disease. Ann. Rev. Med. 1965, 16, 119.

40. Sternlieb, I., and I. H. Scheinberg. Ceruloplasmin in health and disease. Ann. N. Y. Acad. Sci. 1961, 94, 71.

41. Walshe, J. M., and J. Briggs. Cæruloplasmin in liver disease. A diagnostic pitfall. Lancet 1962, 2, 263.

42. Gault, M. H., J. Stein, and A. Aronoff. Serum ceruloplasmin in hepatobiliary and other disorders: significance of abnormal values. Gastroenterology 1966, 50, 8.

43. Gopalan, C., V. Reddy, and V. S. Mohan. Some aspects of copper metabolism in protein-calorie malnutrition. J. Pediat. 1963, 63, 646.

44. Sternlieb, I., and H. D. Janowitz. Absorption of copper in malabsorption syndromes. J. clin. Invest. 1964, 43, 1049. 